\title{
Pengaruh Pembelajaran Saintifik Example Non Example Terhadap Minat Belajar
}

\author{
*Putri Oktavia Wulan Sari ${ }^{1}$, Naniek Sulistya Wardani ${ }^{2}$, Tego Prasetyo ${ }^{3}$
}

${ }_{123}$ Pendidikan Guru Sekolah Dasar, Fakultas Ilmu Pendidikan, Universitas Kristen Satya Wacana, Kota Salatiga, Indonesia

\author{
A R T I C L E I N F O \\ Article history: \\ Received 10 May 2019 \\ Received in revised form \\ 10 June 2019 \\ Accepted 15 July 2019 \\ Available online 29 August \\ 2019 \\ Kata Kunci: \\ saintifik, example non \\ example, minat belajar \\ Keywords: \\ scientific, example non \\ example, interest in learning
}

\begin{abstract}
A B S T R A K
Berdasarkan hasil observasi yang dilakukan oleh peneliti menunjukkan minat belajar siswa masih rendah. Tujuan dari penelitian ini adalah untuk mengetahui apakah terdapat pengaruh pembelajaran saintifik Example Non Example (S-ENE) terhadap minat belajar siswa kelas 4 SD. Jenis penelitian ini adalah penelitian eksperimen dengan desain nonequivalent control group design. Teknik pengambilan sampel adalah purposive stratified quota sampling. Teknik pengumpulan data menggunakan observasi dengan instrumen lembar observasi yang dilengkapi rubrik penilaian minat belajar. Teknik analisis data menggunakan uji t. Kelas eksperimen dan kelas kontrol berdistribusi normal yakni df. 24, sig. 0,129 > 0,05, dan df. 27, sig.0,053 > 0,05. Kedua kelas eksperimen dan kontrol adalah homogen yang ditunjukkan dengan sig. 0,723>0,05. Hasil penelitian menunjukkan sig. (2-tailed) $0,000<0,05$, maka terdapat pengaruh yang signifikan pembelajaran $S$ ENE terhadap minat belajar siswa kelas 4 SD. T-hitung 4,802 > 2,095 ttabel, maka terdapat perbedaan pembelajaran S-ENE dan
\end{abstract} pembelajaran langsung terhadap minat belajar siswa kelas 4 SD.

\begin{abstract}
A B S T R A C T
The purpose of this study was to determine whether the influence of Example Non Example (S-ENE) scientific learning on the learning interest of 4th grade students. This research was experimental research with the design of Posttest Only Control Group Design. The sampling technique used Purposive Stratified Quota Sampling. The data collected by an observation sheet that equipped with an assessment rubric for learning interest. The data analysis technique use the $t$ test. The experimental class and the control class are normally distributed, df. 24 and sig. $0.129>0.05$ and df. 27 and sig.0,053>0.05. Both experimental and control classes are homogeneous as indicated by sig. $0.723>0.05$. The results showed sig. (2-tailed) $0,000<0,05$, then there is a significant effect of S-ENE learning on the learning interest of 4th grade students. T-count is 4.802> $2.095 \mathrm{t}$-table, so there are differences in S-ENE learning and direct learning on the learning interest of 4th grade students.
\end{abstract}

\section{Pendahuluan}

Pendidikan merupakan wahana untuk meningkatkan dan mengembangkan kualitas sumber daya manusia. Selain itu, pendidikan adalah seperangkat proses berupa penanaman nilai, gagasan, konsep dan teori-teori yang bertujuan mengembangkan kepribadian, pengetahuan, keterampilan, dan tingkah laku serta mencapai cita-cita dan tujuan hidup. Salah satu masalah pokok dalam pembelajaran pada pendidikan formal (sekolah) ini adalah masih rendahnya daya serap peserta didik. Hal ini mendorong peserta didik untuk memiliki kemampuan yang membutuhkan pemikiran secara kritis, kreatif, logis, dan kemauan bekerja sama sehingga mampu menyelesaikan permasalahan yang dihadapi. Kegiatan belajar mengajar mengandung sejumlah komponen yang meliputi tujuan, bahan pelajaran, kegiatan belajar mengajar, metode, alat, dan sumber serta penilaian. Dari semua komponen tersebut metode mengajar merupakan salah satu komponen yang sangat penting dalam upaya pencapaian tujuan belajar. Karena pada hakikatnya proses belajar mengajar merupakan suatu upaya agar peserta didik mampu

Copyright (c) Universitas Pendidikan Ganesha. All rights reserved. 
mengintegrasikan berbagai pengalaman sehingga dapat mencapai tujuan belajar yang diinginkan, dan diharapkan pula peserta didik mampu memahami materi yang disampaikan(Eva, 2016) .

Pendidikan merupakan usaha sadar untuk mewujudkan suasana belajar dan proses pembelajaran agar peserta didik secara aktif mengembangkan potensi dirinya. Melalui pendidikan peserta didik juga mendapatkan pembelajaran tentang bagaimana belajar, meningkatkan prestasi, bersosialisasi, dan menjadi seseorang yang berbudi pekerti. Keseluruhan proses pendidikan yang diselenggarakan oleh lembaga pendidikan baik lembaga formal, informal, maupun non formal, merupakan kegiatan yang paling pokok bagi anak guna mencapai tujuan pendidikan. Belajar sendiri berhubungan dengan perubahan tingkah laku seseorang tehadap situasi tertentu yang disebabkan oleh pengalamannya.

Penyelenggaraan pendidikan sebagaimana diamanatkan dalam Undang- undang Nomor 20 tahun 2003 tentang Sistem Pendidikan Nasional diharapkan dapat mewujudkan proses berkembangnya kualitas pribadi peserta didik sebagai generasi penerus yang akan menjadi pengaruh baik bagi bangsa dan negara Indonesia sepanjang zaman. Pemerintah telah berupaya melakukan inovasi pada zaman modern ini dalam hal pendidikan dengan penerapan kurikulum 2013 berbasis tematik terpadu atau tematik integratif. Permendikbud No. 22 Tahun 2016 tentang Standar Proses menekankan bahwa pembelajaran tematik terpadu menuntut siswa lebih aktif mengembangkan potensi dirinya, sehingga diperlukan model pembelajaran yang tepat dan sesuai dengan karakteristik siswa. Keaktifan siswa ketika pembelajaran dapat dilihat jika siswa memiliki minat belajar yang tinggi.

Dalam pembelajaran, guru banyak yang menggunakan model pembelajaran konvensional dalam proses pembelajaran berlangsung. Agustina(2011:66) juga menjelaskan bahwa dalam pembelajaran konvensional, guru cenderung lebih aktif sebagai sumber informasi atau sumber belajar bagi siswa dan siswa cenderung pasif saat mengikuti pembelajaran. Pembelajaran konvensional merupakan pembelajaran yang lebih berpusat pada guru seperti pembelajaran langsung dan kurang dapat meningkatkan minat belajar siswa yang mengakibatkan siswa sulit berperan aktif ketika mengikuti pembelajaran.

Dalam pembelajaran langsung guru berperan penuh memberikan materi, guru sepenuhnya menggunakan metode ceramah sehingga aktivitas siswa tidak menjadi perhatian guru. Sehingga dalam pembelajaran langsung tidak nampak dari seluruh siswa tekun dalam belajar, tidak nampak adanya kerjasama dalam belajar, sebagian siswa kurang memiliki rasa ingin tahu dan disiplin dalam belajar. Kondisi ini tidak nampak minat belajar siswa. Minat belajar siswa yang rendah berdampak pada hasil belajar siswa yang hanya tuntas $38 \%$ saja, sehingga $62 \%$ siswa belum tuntas dalam pembelajarannya. Untuk itu diperlukan adanya strategi pembelajaran baru guna meningkatkan kualitas proses pembelajaran. Pemilihan pendekatan dan model pembelajaran yang inovatif sangat dibutuhkan untuk meningkatkan minat belajar siswa terutama pada pembelajaran tematik terpadu.

Dalam kurikulum 2013 menekankan kompetensi siswa yang berbeda dengan penekanan kurikulum sebelumnya. Kurikulum 2006 tujuan pembelajaran menekankan pada materi pembelajaran yang nampak di beberapa sekolah masih ada guru yang kurang memperhatikan ketercapaian kompetensi peserta didik. Guru selalu melakukan pembelajaran secara konvensional dan pembelajaranya langsung. Pembelajaran masih berpusat pada guru dan membuat siswa pasif. Kondisi itulah yang selalu ada dalam pembelajaran langsung. Permasalahannya apakah kondisi pembelajaran langsung ini dapat dicoba dengan menggunakan pembelajaran saintifik model example non example yang disarankan dalam kurikulum 2013. Kurikulum 2013 menekankan pencapaian kompetensi. Pembelajarannya menggunakan saintifik dan melibatkan siswa untuk belajar. Keterlibatan siswa akan mendorong minatnya melakukan aktifitas belajar. Cara inilah yang dalam penelitian ini akan dilakukan dalam sebuah eksperimen pembelajaran dikelas.

Permasalahan yang dirumuskan dalam penelitian ini adalah apakah terdapat pengaruh pembelajaran saintifik example non example (S-ENE) terhadap minat belajar tematik siswa kelas 4 SD. Pembelajaran sainitifik Example Non Example (S-ENE) merupakan aktivitas proses pembelajaran dengan menggunakan media gambar untuk mendorong siswa dalam mengkonstruksi konsep, hukum, atau prinsip. Ada 7 langkah dalam pembelajaran saintifik. Menurut Hosnan (2014). Daryanto (2014) langkah dalam pembelajaran saintifik sebagai berikut: : 1) Meyimak penjelasan dari guru terkait materi 2) Menanya materi pembelajaran 3) Menalar jawaban atas pertanyaan yang diajarkan 4) Mengumpulkan informasi melalui berbagai sumber 6) Menarik kesimpulan 7) Mengkomunikasikan tentang apa yang sudah dipelajari.

Pelaksanaan pembelajaran saintifik dapat didesain dengan model example non example. Model ini menurut Joyce \& dkk, (2009), Utari, Degeng, \& Akbar (2016:21) danHuda (2013:234) model Example Non Example merupakan model pembelajaran yang banyak menggunakan gambar-gambar untuk menyampaikan penjelasan materi yang diajarkan. Model Example Non Example menurut Slavin dalam Hamdayama (2014:99), dengan langkah- langkah sebagai berikut : (1) Mengamati gambar dan penjelasan 
guru, (2) Membentuk kelompok @ 6 siswa, (4) Menganalisis gambar dan mencatat, (5) Membacakan hasil diskusi, (6) Memberi tanggapan, (7) Menyimak penjelasan materi oleh guru, (8) Menarik kesimpulan.

Pembelajaran S-ENE dikelas, dapat dilaksanakan melalui langkah-langkah sebagai berikut (1) Menyimak materi (2) Membentuk kelompok beranggotakan 6 siswa(3) Menanya tentang maksud gambar, (4) mendeskripsikan ciri- ciri gambar (5) berdiskusi tentang ciri-ciri gambar (6) Menyimpulkan hasil diskusi dari berbagai pendapat teman (7) Melaporkan hasi l diskusi. Desain pembelajaran S-ENE untuk Tema 8 Subtema 2 Pembelajaran 5 terdiri dari 3 mata pelajaran yaitu Bahasa Indonesia dengan KD 3.9 dan 4.9, PPKn dengan KD 3.3 dan 4.3, sedangkan SBdP dengan KD 3.3 dan 4.3 melalui langkah-langkah: (a) Menyimak gambar tarian daerah dan macam-macam kegemaran, (b) membentuk kelompok @ 6 orang, (c) Menanya gambar ciri- ciri tarian daerah dan macam- macam kegemaran, (d) Mendeskripsikan tentang ciri- ciri tarian daerah dan macam- macam kegemaran, (e) Berdiskusi tentang ciri- ciri tarian daerah dan macam- macam kegemaran, (f) Menyimpulkan hasil diskusi dari berbagai pendapat teman, (g) Melaporkan hasil diskusi bersama kelompok. Siswa senang dan tidak terasa kalau aktivitas itu merupakan upaya guru mendorong siswa untuk melakukan aktifitas belajar, sehingga minat belajar siswa dapat dideteksi.

Dorongan yang dilakukan guru dan siswa melakukan aktivitas belajar merupakan bentuk minat belajar. Menurut Djamarah (2011:132), dan Slameto (2010:176) minat adalah rasa lebih suka dan rasa ketekunan, rasa ingin tahu, dan ketertarikan terhadap kegiatan pembelajaran. Rasa lebih suka dan ketekunan, dorongan, rasa ingin tahu, dan ketertarikan dan sebagainya akan terwujud dan teramati melalui tingkat laku yang berupa aktivitas belajar. Dengan demikian, minat belajar dapat diamati melalui aktivitas belajar yang berupa 1) Ketekunan dalam belajar (nampak melalui mengamati gambar, mau mendeskripsikan gambar) 2) Rasa ingin tahu (yang nampak melalui bertanya tentang materi dan mengerjakan soal latihan) 3) Kerjasama (nampak melalui mau membentuk kelompok, membahas soal, dan berdiskusi terkait materi) 4) Disiplin dalam belajar (dapat ditandai dengan tidak menganggu teman saat kegiatan pembelajaran, mengumpulkan tugas tepat waktu).

Pembelajaran S-ENE merupakan pembelajaran inovatif dalam kurikulum 2013 dan akan digunakan sebagai percobaan, dan sebagai pembandingnya adalah pembelajaran konvensional. Menurut Abdul, (2014:184) pembelajaran konvensional yaitu pembelajaran klasikal yang berpusat pada guru, sehingga siswa cenderung pasif dan kegiatan pembelajaran hanya mengajarkan konsep bukan kompetensi. Pembelajaran konvensional dapat dilaksanakan melalui langkah- langkah berikut menurut Nella, Eka Kresna (2014) sebagai berikut: 1) Menyimak materi pembelajaran, 2) bertanya jawab tentang materi, 3) memberikan latihan, 4) membahas soal latihan, 5) Menyimpulkan inti pelajaran. Pembelajaran konvensional adalah pembelajaran yang menggunakan langkah-langkah: Menyimak materi pada Tema 8 subtema 2, bertanya jawab tentang ciri- ciri tarian daerah dan kegemaran, mengerjakan soal latihan tentang ciri- ciri tarian daerah dan kegemaran, membahas soal tentang ciri- ciri tarian daerah dan kegemaran, Menyimpulkan inti ciri- ciri tarian daerah dan kegemaran.

Minat belajar adalah besarnya skor dari 1) Ketekunan dalam belajar ciri-ciri tarian daerah dan kegemaran (menyimak materi, mengamati gambar, mendeskripsikan gambar, mengerjakan latihan soal), 2) Rasa ingin tahu dalam belajar ciri-ciri tarian daerah dan kegemaran (bertanya jawab tentang gambar), 3) Kerjasama dalam belajar ciri-ciri tarian daerah dan kegemaran ( membentuk kelompok, berdiskusi, menyimpulkan hasil diskusi, membahas soal latihan), 4) Disiplin dalam belajar ciri-ciri tarian daerah dan kegemaran (melaporkan hasil diskusi, menyimpulkan inti pelajaran).

Penjelasan pengaruh pembelajaran S-ENE terhadap minat belajar siswa kelas 4 tersebut di atas dapat dibuat secara rinci, seperti disajikan melalui gambar 1 sebagai berikut: 

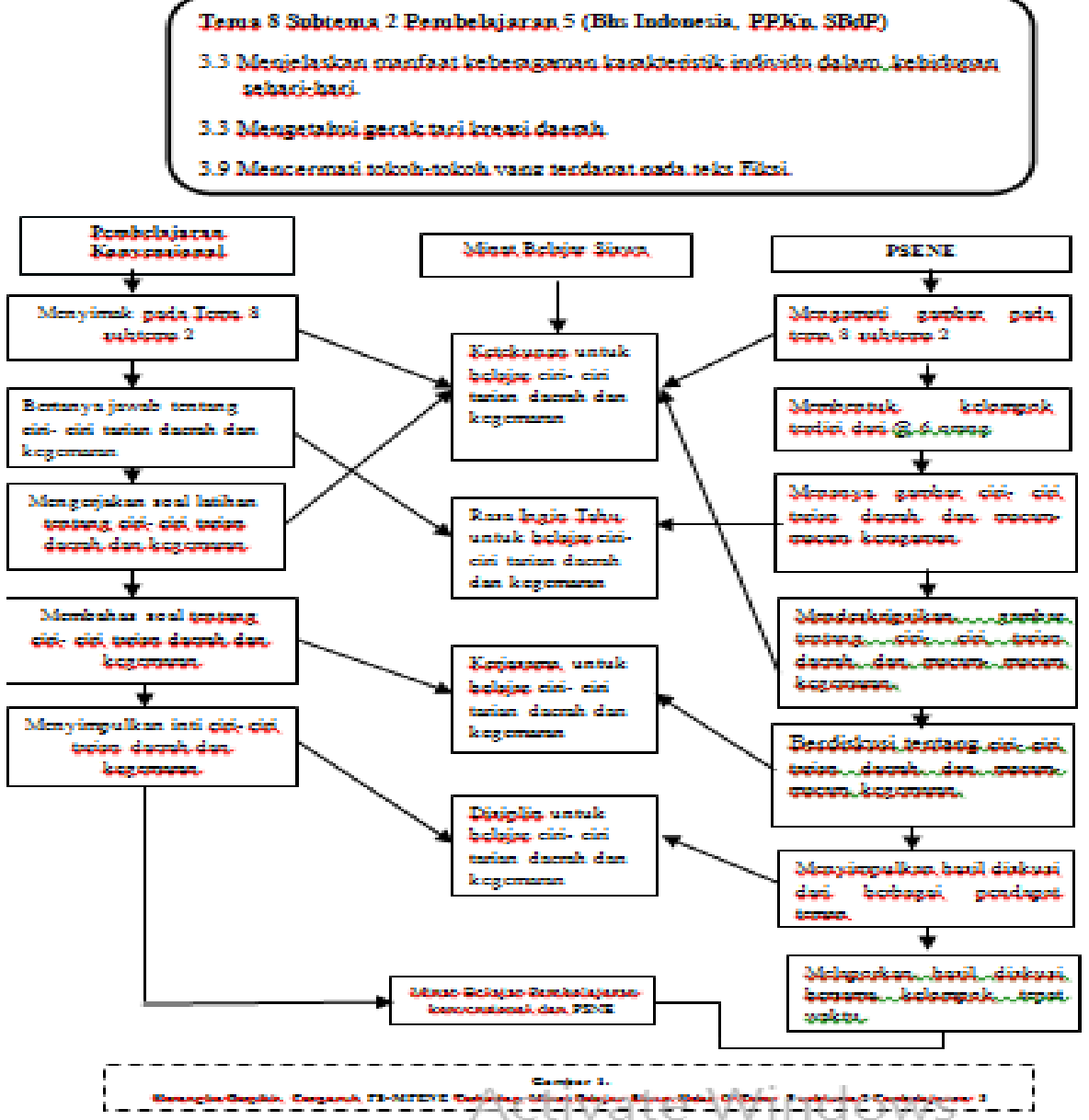

Gambar 1.

Kerangka Berpikir Pengaruh Pembelajaran S-ENE Terhadap Minat Belajar Siswa Kelas 4 SD

\section{Metode}

Jenis Penelitian ini adalah penelitian eksperimen dengan menggunakan desain nonequivalent control group design. Teknik pengumpulan data menggunakan observasi dengan instrumen lembar observasi yang dilengkapi rubrik penilaian minat belajar. Teknik pengambilan sampel adalah purposive stratified quota sampling artinya pengambilan sample dengan menentukan tujuan terlebih dahulu, yaitu siswa yang berminat belajar, kemudian menentukan strata/ kelas IV danmenentukan quota/ jumlah lebih dari 25 siswa per kelas. Penelitian eksperimen ini akan menyelidiki hubungan sebab dan akibat antara kelas eksperimen yang diberi perlakuan dan kelas kontrol yang tanpa perlakuan. Desain eksperimen penelitian ini secara rinci disajikan dalam tabel 1 sebagai berikut.

Tabel 1. Desain Eksperimen

\begin{tabular}{lll}
\hline $\mathbf{O}_{1}$ & $\mathrm{X}$ & $\mathbf{O}_{2}$ \\
\hline $\mathbf{O}_{3}$ & & $\mathbf{O}_{4}$ \\
\hline
\end{tabular}

\section{Keterangan:}

$\begin{array}{ll}\mathbf{X} & \text { : Perlakuan menggunakan MP S-EnE } \\ \mathbf{O}_{1} & \text { : Pengukuran pretest kelompok eksperimen } \\ \mathbf{O}_{2} & \text { : Pengukuran posttest kelompok eksperimen } \\ \mathbf{O}_{3} & \text { : Pengukuran pretest kelompok kontrol } \\ \mathbf{O}_{4} & \text { : Pengukuran posttest kelompok control }\end{array}$


Penelitian ini dilakukan di SD Negeri Tegalrejo 02 Salatiga yang terletak di Jalan Veteran-Tegalrejo No. 1 Argomulyo, Tegalrejo, Kota Salatiga. Variabel penelitian adalah pendekatan saintifik sebagai variabel bebas dan minat belajar siswa sebagai variabel terikat.

Teknik analisis data menggunakan uji $\mathrm{t}$ (Independent Sample t-test) dengan syarat terdapat homogenitas dan normalitas data. Untuk memenuhi persyaratan homogenitas dan normalitas, terlebih dahulu instrumen penelitian dilakukan validitas. Penelitian ini menggunakan teknik pengumpulan data non tes. Instrumen non tes yang digunakan adalah lembar pedoman observasi, instrumen ini digunakan untuk mengukur minat belajar siswa kelas IV.

\section{Hasil dan Pembahasan}

Pada Teknik analisis data dengan uji independent sample t-test digunakan untuk menguji hipotesis dengan kriteria sebagai berikut.

Ho : Tidak terdapat perbedaan pembelajaran saintifik ENE terhadap minat belajar siswa kelas 4 Tema 8

Subtema 2 Pembelajaran 5 di SD Negeri Tegalrejo 02 Salatiga semester 2 tahun pelajaran $2018 / 2019$.

Ha : Terdapat perbedaan pembelajaran saintifik ENE terhadap minat belajar siswa kelas 4 Tema 8 Subtema 2 Pembelajaran 5 di SD Negeri Tegalrejo 02 Salatiga semester 2 tahun pelajaran $2018 / 2019$.

Uji normalitas digunakan untuk mengetahui apakah data pretest kelas eksperimen dan kelas kontrol berdistribusi normal atau tidak. Pengujian normalitas data menggunakan bantuan uji KolmogorovSmirnov jika jumlah responden kurang dari 50, dengan acuan sebagai berikut 1) Jika nilai signifikansi < 0,05 maka data tidak berdistribusi normal 2) Sedangkan jika nilai signifikansi > 0,05, maka data berdistribusi normal. Hasil uji normalitas kelas eksperimen dan kelas kontrol disajikan dalam tabel 2 sebagai berikut.

Tabel 2. Hasil Uji Normalitas Kelas Eksperimen dan Kelas Kontrol

\begin{tabular}{lccc}
\hline & \multicolumn{2}{c}{ Kolmogorov-Smirnov $^{2}$} & Sig \\
\hline Kelas Eksperimen & Statistic & df & .129 \\
Kelas Kontrol & .935 & 24 & .053 \\
\hline
\end{tabular}

Berdasarkan tabel 2 hasil uji normalitas kelas eksperimen, signifikansi sebesar 0,129 lebih besar dari 0,05 $(0,129>0,05)$, hasil uji normalitas kelas kontrol diperoleh signifikansi sebesar 0,053 lebih besar dari $0,05(0,053>0,05)$, maka disimpulkan dari hasil pretest distribusi kelas eksperimen dan kelas kontrol berdistribusi normal dan homogen. Hasil uji homogenitas data pretest kelas eksperimen dan kontrol.

Data pretest kelas eksperimen dan kelas kontrol berdistribusi normal, maka tahap berikutnya adalah dilakukan uji homogenitas Uji homogenitas dilakukan untuk mengetahui apakah data posttest kelas eksperimen dan kelas kontrol memiliki varian yang sama atau homogen. Acuan yang digunakan dalam uji homogenitas adalah 1) Jika nilai signifikansi > 0,05, maka data memiliki varian yang sama homogen 2) Jika nilai signifikansi $<0,05$, maka data memiliki varian yang tidak sama atau heterogen. Hasil uji homogenitas kelas eksperimen dan kelas kontrol disajikan dalam tabel 3 sebagai berikut.

Tabel 3. Hasil Uji Homogenitas Kelas Eksperimen dan Kelas Kontrol

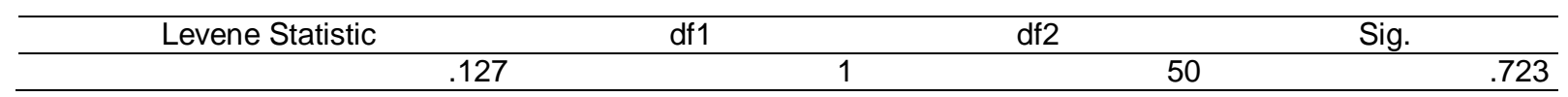

Berdasarkan hasil uji homogenitas instrumen pretest kelas eksperimen dan kelas kontrol signifikansinya sebesar 0,723 lebih besar dari 0,05 (0,723>0,05), leveane statistic sebesar 127 maka dapat disimpulkan kelas eksperimen dan kelas kontrol memiliki varian yang sama atau homogen.

Dari paparan diatas maka dapat disimpulkan uji prasyarat dengan menggunakan uji normalitas dan uji homogenitas telah terpenuhi. Selanjutnya uji hipotesis dilakukan dengan menggunakan uji t (independent sample t-test).

Teknik analisis data dalam penelitian ini adalah uji independent sample t-test, dengan melakukan pengujian data posttest kelas eksperimen menggunakan pembelajaran S-ENE terhadap data posttest kelas kontrol menggunakan pembelajaran konvensional. Acuan pengambilan keputusan adalah 1) Jika signifikansi (2-tailed) < 0,05, maka Ho ditolak dan Ha diterima, 2) Jika signifikansi (2-tailed) > 0,05, maka 
Ho diterima dan Ha ditolak. Uji independent sample t-test dilakukan dengan bantuan SPSS versi 20. Hasil uji independent sample t-test disajikan dalam tabel 4 sebagai berikut.

Tabel 4. Hasil Uji Independent Sample t-test

\begin{tabular}{|c|c|c|c|c|c|c|c|c|c|c|}
\hline & & $\begin{array}{l}\text { Levene'sTest } \\
\text { for Equality }\end{array}$ & & & & test for $\mathrm{E}$ & uality & F Means & & \\
\hline & & $\mathrm{F}$ & Sig & $\mathrm{f}$ & $\mathrm{df}$ & $\begin{array}{l}\text { Sig.(2- } \\
\text { tailed }\end{array}$ & $\begin{array}{l}\text { Mean } \\
\text { Differ } \\
\text { ence }\end{array}$ & $\begin{array}{l}\text { Std } \\
\text { Error } \\
\text { Difference }\end{array}$ & $\begin{array}{l}95 \% \\
\text { Confide } \\
\text { Interva } \\
\text { Differe }\end{array}$ & $\begin{array}{l}\text { nce } \\
\text { of the } \\
\text { ce }\end{array}$ \\
\hline & Equal & 1.152 & 28 & 4.80 & 49 & .000 & 4.310 & 1.106 & $\begin{array}{l}\text { Lower } \\
3.088\end{array}$ & $\begin{array}{l}\text { Upper } \\
7.532\end{array}$ \\
\hline & Varian & 1.102 & 8 & 2 & & .000 & 4.510 & 1.100 & & \\
\hline $\begin{array}{l}\text { Belaj } \\
\text { ar }\end{array}$ & $\begin{array}{l}\text { Assume } \\
d\end{array}$ & & & & & & 4.310 & & & \\
\hline & $\begin{array}{l}\text { Equal } \\
\text { Varianc } \\
\text { es not } \\
\text { Assume } \\
\text { d }\end{array}$ & & & $\begin{array}{l}4.86 \\
5\end{array}$ & $\begin{array}{l}48.51 \\
7\end{array}$ & .000 & & 1.092 & 3.116 & 7.504 \\
\hline
\end{tabular}

Berdasarkan tabel 4 hasil uji independent sample t-test diketahui nilai t sebesar 4,802 $>2,095 \mathrm{t}$ tabel) dan nilai signifikansi (2-tailed) $0,000<0,05$, maka dapat disimpulkan Ho ditolak dan Ha diterima artinya terdapat perbedaan pembelajaran saintifik ENE terhadap minat belajar tema 8 subtema 2 pembelajaran 5 siswa kelas 4 SD. Perbedaan rata-rata skor minat belajar kelas eksperimen dan kelas kontrol disajikan dalam tabel 5 sebagai berikut.

Berdasarkan Minat Belajar Kelas Eksperimen dan Kelas Kontrol, diketahui jumlah siswa minat belajar untuk kelas eksperimen 24 siswa dan kelas kontrol sebanyak 27 siswa. Skor rata-rata minat belajar kelas eksperimen sebesar 57,85, dan skor rata-rata minat belajar kelas kontrol sebesar 52,54. Perbedaan rata-rata skor minat belajar antara kelas eksperimen dan kelas kontrol adalah 5,31. Besarnya perbedaan skor rata-rata minat belajar, juga ditunjukkan oleh tabel 5 mean difference 5,310. Dengan demikian, terdapat perbedaan rata-rata minat belajar antara kelas eksperimen dan kelas kontrol. Perbedaan rata-rata minat belajar yang signifikan (nyata) antara kelas eksperimen dan kelas kontrol ditunjukkan oleh nilai signifikansi (2-tailed) $0,000<0,05$, maka Ho ditolak dan Ha diterima. Artinya Terdapat perbedaan pembelajaran S-ST dan pembelajaran konvensional terhadap minat belajar siswa kelas 5 Tema 8 Subtema 2 Pembelajaran 5.

Pembelajaran S-ENE pada siswa kelas 4 SD Negeri Tegalrejo 02 Salatiga sebagai kelas eksperimen menunjukan minat belajar yang lebih tinggi dibandingkan dengan pembelajaran konvensoinal pada siswa kelas 4 SD Negeri Tegalrejo 02 Salatiga sebagai kelas kontrol. Berdasarkan hasil penelitian diketahui bahwa pada kelas eksperimen sebanyak 15 siswa termasuk dalam kategori sangat berminat dengan persentase 62,5\%, 9 siswa termasuk dalam kategori berminat dengan persentase 37,5\%,. Sedangkan pada kelas kontrol sebanyak 14 siswa termasuk dalam kategori sangat berminat dengan persentase $51,8 \%, 13$ siswa termasuk dalam kategori berminat dengan persentase $48,1 \%$.

Hasil penelitian yang sejenis dan mendukung hasil penelitian ini, dilakukan oleh Nurhadi, Anitah, \& Akhyar(2014) dengan judul Perbedaan Pengaruh Penerapan Model Pembelajaran Kooperatif Tipe Exampel Non Exampel Dan Jigsaw Terhadap Minat Belajar. Hasil rata-rata minat belajar kelas eksperimen 67,75 adalah dan kelas kontrol adalah 62,59. Jadi ada perbedaan rata-rata minat belajar antara kelas eksperimen dan kelas kontrol sebesar 5,16

Hasil penelitian Kartikowati, juga dihasilkan dalam penelitian ini bahwa terdapat perbedaan ratarata minat belajar antara kelas pembelajaran S-ENE dan kelas pembelajaran konvensional sebesar 4,310. Penelitian lain yang sejalan, dilakukan oleh Wardika, pada tahun 2014 menemukan signifikansi minat belajar siswa pada kelas kontrol sebesar 0,058 > 0,05 dan signifikansi minat belajar siswa pada kelas eksperimen sebesar 0,129>0,05 kategori sangat berminat. Begitu juga dalam penelitian ini, memperoleh signifikansi minat belajar sebesar $0,021<0,05$. Maka Ho ditolak. Penelitian lain yang sejalan dilakukan oleh Putra, dkk pada tahun 2016. Hasil penelitian menunjukkan terdapat perbedaan minat belajar siswa antara pembelajaran example non example dan pembelajaran non example non example dengan 
signifikansi 2-tailed 0,018<0,05. Maka Ho ditolak, artinya bahwa terdapat perbedaan minat belajar siswa antara kelas ekperimen dan kelas kontrol. Hasil penelitian basyir sama dengan hasil penelitian ini yang signifikansi 2-tailed 0,000 <0,05.

Hasil analisis skor rata-rata minat belajar siswa kelas eksperimen dengan pemberian perlakuan S-ENE dan skor rata-rata minat belajar siswa kelas kontrol dengan tidak ada pemberian perlakuan menunjukkan, perbedaan skor rata-rata minat belajar kelas eksperimen lebih tinggi dibandingkan dengan skor rata-rata minat belajar kelas kontrol. Maka dari itu terdapat pengaruh pembelajaran S-ENE terhadap minat belajar siswa. Pendekatan yang didasarkan pada prinsip bahwa cara belajar terbaik bagi peserta didik adalah dengan melakukan, dengan menggunakan semua inderanya, dan dengan mengeksplorasi lingkungannya yang terdiri atas orang, hal, tempat dan kejadian yang terjadi dalam kehidupan sehari-hari peserta didik (pembelajaran kontekstual). (Wardani Naniek Sulistya, 2012)

\section{Simpulan dan Saran}

Hasil penelitian menunjukkan nilai signifikansi (2-tailed) $0,000<0,05$, maka: Ho ditolak artinya terdapat perbedaan pembelajaran S-ENE dan pembelajaran konvensional terhadap minat belajar siswa kelas 4 Tema 8 Subtema 2 Pembelajaran 5, dan Ha diterima artinya terdapat perbedaan pembelajaran SENE dan pembelajaran konvensional terhadap minat belajar siswa kelas 5 Tema 8 Subtema 2 Pembelajaran 5. Hasil penelitian juga menunjukkan t hitung sebesar 4,802 > 2,095 t tabel, maka Ho ditolak dan Ha diterima. Artinya terdapat perbedaan rata-rata minat belajar siswa antara pembelajaran S-ENE dan pembelajaran konvensional.

\section{Daftar Rujukan}

Abdul, M. (2014). Strategi Pembelajaran. Bandung: Remaja Rosdakarya.

Agustina, Y. (2011). Kemampuan Guru Menciptakan Iklim Komunikatif di kelas. Jakarta: Aditya Media Publish.

Daryanto. (2014). Pendekatan Pembelajaran Saintifik Kurikulum 2013. Yogyakarta: Penerbit Gaya Media.

Djamarah, S. (2011). Psikologi Belajar. Jakarta: Rineka Cipta.

Departemen Pendidikan \& Kebudayaan. 2016. Peraturan Menteri Pendidikan \& Kebudayaan Republik Indonesia Nomor 22 Tahun 2016 Tentang Standar Proses Pendidikan Dasar \& Menengah. Jakarta.

Eva, M. (2016). Pengaruh penggunaan model pembelajaran kooperatif tipe student facilitator and explaining terhadap pemahaman matematik peserta didik. Jurnal Penelitian Pendidikan Dan Pengajaran Matematika, 2(1), 29-34.

Hamdayama, J. (2014). Model dan Metode Pembelajaran Kreatif dan Berkarakter. Bogor: Ghalia Indonesia.

Hosnan. (2014). Pendekatan Saintifik dan Kontekstual dalam Pembelajaran Abad 21. Bogor: Ghalia Indonesia.

Huda, M. (2013). Model-Model Pengajaran dan Pembelajaran. Yogyakarta: Pustaka Pelajar.

Joyce, B., \& dkk. (2009). Models of Teaching. Yogyakarta: Pustaka Pelajar.

Nurhadi, M., Anitah, S., \& Akhyar, M. (2014). Perbedaan Pengaruh Penerapan Model Pembelajaran Kooperatif Tipe Exampel Non Exampel Dan Jigsaw Terhadap prestasi Belajar Pendidikan Kewarganegaraan (Pkn) Ditinjau Dari Minat Belajar Siswa SD N Di Kecamatan Undaan Kabupaten Kudus. Jurnal Teknologi Pendidikan Dan Pembelajaran, 2(1), 113-126.

Slameto. (2010). Belajar dan Faktor-Faktor yang Mempengaruhi. Jakarta: Ranika Cipta.

Utari, U., Degeng, I. N. S., \& Akbar, S. (2016). Pembelajaran tematik berbasis kearifan lokal di sekolah dasar dalam menghadapi Masyarakat Ekonomi Asean (MEA). Jurnal Teori Dan Praksis Pembelajaran IPS, $1(1)$. 